\title{
HIERACIA BALCANICA IX. TYPIFICATION OF THE HIERACIUM (ASTERACEAE) NAMES DESCRIBED BY J. FREYN FROM THE BALKAN PENINSULA
}

\author{
ZBiGNIEW SZELĄG
}

\begin{abstract}
Thirteen names in Hieracium L. described by Josef Freyn from the Balkan Peninsula are lectotypified from among specimens stored at BRNM. For one species the holotype was found in BRNM. All discussed taxa are illustrated by photos of original specimens.
\end{abstract}

Key words: Baldacci, Balkan Peninsula, Brandis, Hieracium, Sintenis, typification, Vandas, Velenovský

Zbigniew Szelag, Pedagogical University of Cracow, Department of Botany, Podchorążch 2, 30-084 Kraków, Poland; e-mail: azszelag@wp.pl

\section{INTRODUCTION}

Continuing a revision of Josef Freyn's collection in the Moravian Museum in Brno (cf. Szeląg 2012), I found original material for 14 Hieracium L. taxa of Freyn described from the Balkan Peninsula (Freyn 1876, 1891, 1895, 1897). They were based on material collected by Karel Vandas (1861-1923) and Josef Velenovský (1858-1949) in Bulgaria and Herzegovina, Antonio Baldacci (1867-1950) in Albania, Erich Brandis in Bosnia, Paul Ernst Emil Sintenis (1847-1907) in Greece, as well as personally by Freyn in Croatia.

Access to original herbarium material or at least illustrations for comparison is crucial when determining collected Hieracium specimens; therefore all lectotypes designated in this paper and one holotype are illustrated (Figs 1-14).

\section{RESULTS}

\section{Hieracium albanicum Freyn}

Fig. 1

Bull. Herb. Boissier 3: 651, 666. 1895 - TYPE LOCALITY: 'Albania, in alpinis montis Stoge (Acroceraunia) die 10. julio 1892 leg. Baldacci (exs. 211 pro H. calophyllum f. pseudophyllopoda mihi); Hercegovina, Mostar: Kalkfelsen der Porim-Planina, 21. Aug. 1889 leg. Vandas (als H. gymnocephalum var. ? mihi)' - LестотуPE (designated here): in alpinis $\mathrm{m}$. Stoge (Acroceraunia), 10.07.1892, A. Baldacci 211 (BRNM 7289/36) - SYNTYPE: Hecegovina, Kalkfelsen der Porim-planina (Mostar Kreis), 21.08.1889, K. Vandas (BRNM 7290/36).

\section{Hieracium argyrotrichum Freyn}

Fig. 2

in Velenovský, Fl. Bulg.: 349. 1891 - TyPE LOCALity: 'In rupestribus declivium m. Rhodope supra Dermendere et Sotir (Vel.)' - LectotyPe (designated here): Flora Bulgarica. In rupestribus decliv. m. Rhodope supra Dermendere, Aug 1889, J. Velenovský (BRNM 8297/36).

\section{Hieracium aridum Freyn}

Fig. 3

Oesterr. Bot. Z. 26(1): 369. 1876 - TYPE LOCALITY: 'Habitat in colle aridissimo quem Monte Pero dicunt ad urbem Pola Istriae, in societate $H$. adriatici Näg. (florentis), H. pilosellae L. (defloratae) et $H$. florentini All. (florentis) rarissimum' - HoLOTYPE: Istrien. Wegränder oberhalb der Eisenbahn S. Abhange des Mte. Pero bei Pola, im Gesellschaft von H. adriaticum Näg. (blüh.) H. florentinum All. (blüh.) und H. pilosella (verblüht). Bodenunterlage: Kalk. Seehöhe: 50 m, 9.06.1876, J. Freyn (BRNM 12174/36).

\section{Hieracium bosniacum Freyn}

Fig. 4

Bull. Herb. Boissier 3: 508, 654. 1895 - TyPE LOCALITY: 'Bosnien, Staribrod an der serbischen Grenze, in $273 \mathrm{~m}$. 
Seehöhe, am 28. Juli 1894 leg. Brandis' - LectotyPe (designated here): Flora Bosniaca. Staribrod 273 mt., 28.07.1894, E. Brandis (BRNM 7244/36).

Hieracium dolopicum Freyn \& Sint.

Fig. 5

Bull. Herb. Boissier 5: 785. 1897 - TyPE LOCALITY: 'Thessalia graecca, Pindus dolopicus: ad parietes rupium in cacumine montis Coccino-Lithari prope Sermoniko die 21. aug. 1896 leg. Sintenis (exs. 1265)' - LECTOTYPE (designated here): Pindus dolop. Sermeniko: ad parietes rupium in summo montis Coccino-Lithari, 21.08.1896, P. Sintenis 1265 (BRNM 7245/36) - IsOLECTOTYPES: BRNM 7246/36, BRNM 7247/36.

Note. According to Freyn (1897: 786) Hieracium dolopicum is similar to $H$. odontophyllum Freyn \& Sint. from Turkey. I saw the original specimen of H. odontophyllum (Szeląg 2012: 366, fig. 16), which in my opinion is a hybrid of the morphological formula $H$. pannosum $-H$. umbellatum, which does not fit $H$. dolopicum at all. In my opinion, $H$. dolopicum is similar to $H$. pannosiformae Freyn \& Sint., another species also from Turkey (Szeląg 2012: 360, fig. 10).

Hieracium dolopicum var. minus Freyn \& Sint.

Fig. 6

Bull. Herb. Boissier 5: 786. 1897 - TyPE LOCALiTY: 'Thessalia graecca, Pindus dolopicus: ad parietes rupium montis Skala prope Sermeniko die 10. aug. 1896 leg. Sintenis (exs. 1129)' - LeCtotyPe (designated here): Thessalia graecca, Pindus dolopicus: ad parietes rupium montis Skala prope Sermeniko, 10.08.1896, P. Sintenis 1129 (BRNM 7248/36).

Note. An examination of the type material of $H$. dolopicum s.str. and H. dolopicum var. minus revealed that they are not separable and must be considered conspecific.

\section{Hieracium eriobasis Freyn \& Sint.}

Fig. 7

Bull. Herb. Boissier 5: 787. 1897 - TyPe LOCALity: 'Thessalia graecca, Pindus tymphaeus: ad rupes montis Turnara prope Chaliki die 26. junio 1896 leg. Sintenis (exs. 738)' - Lectotype (designated here): Pindus tymph. Chaliki: ad rupes montis Turnara versus montem Saltura, 26.06.1896, P. Sintenis 738 (BRNM 7260/36).

Note. According to Freyn (1897: 787), Hieracium eriobasis is a hybrid of the morphological formula $H$. candicans $>H$. villosum. However, Zahn (1921: 584) regards $H$. eriobasis as a hybrid between $H$. pannosum and $H$. murorum. In my opinion, $H$. eriobasis belongs to $H$. sect. Oreadea.

Hieracium flexicaule Freyn \& Vandas Fig. 8

Bull. Herb. Boissier 3: 645, 666. 1895 - TYPE LOCALITY: 'Hecegovina, in declivitatibus saxosis montis VeleschPlanina prope Smrtschanj, aug. 1893, leg. Vandas (exs. 16)' - LестотуPE (designated here): Flora Hercegovinae centralis. In declivitat. saxosis mont. Velež pl. prope Smrčanj, Aug 1893, K. Vandas 16 (BRNM 7252/36).

\section{Hieracium scheppigianum Freyn}

Fig. 9

Bull. Herb. Boissier 3: 651, 665. 1895 - TyPE LOCALITY: 'Hecegovina, Trebinje: in saxosis montis Vutschi Zub rarum, julio 1891 leg. Vandas (pro H. flexuoso); in declivitatibus saxosis montis Prasa supra vallem Dobri Do 1400 m. s. m., aug. 1891 leg. Vandas (pro H. flexuosum $\times$ orieni $?$ mihi)' - LECTOTYPE (designated here): Flora Hercegovinae centralis. In saxosis summi montis Vuči zub rarum (distr. Trebinje), Jun $1891 \mathrm{~K}$. Vandas (BRNM 7250/36) - SyNTYPE: Flora Hercegovinae centralis. In declivitatibus saxosis montis Prasa supra vallem Dobri do ca. 1400 m s. m. (prope Trebinje), Aug 1891, K. Vandas (BRNM 7251/36).

\section{Hieracium secundum Freyn}

Fig. 10

in Velenovský, Fl. Bulg.: 352. 1891 - TYPE LOCALiTY: 'In graminosis alpinis in formatione juniperina m. Osogovska Planina (Vel. Vs.)' - Lectotype (designated here): Bulgaria. Osogovo Planina ad confines Macedoniae. Auf mehreren Stellen in der Juniperus Formation mit H. eriopus vermischt, Aug 1887, Velenovský \& Vandas (BRNM 8574/36).

Hieracium sermonikense Freyn \& Sint. Fig. 11

Bull. Herb. Boissier 5: 790. 1897 - TYPe LOCALITY: 'Thessalia graecca, Pindus dolopicus: in silvis prope Sermoniko supra pagum Bezula cum $H$. racemoso W. K. forma die 18. aug. 1896 (exs. 1197); Volo: in fagetis montis Pelion die 5. sept. 1896 (exs. 1277) leg. Sintenis'- LeстотуPe (designated here): Pindus dolopicus Sermoniko in silvis supra Bezula, 18.08.1896, P. Sintenis 1197 (BRNM 8553/36) - ISOLECTOTYPE: (BRNM 8552/36) - SyntyPes: Velo; in fagetis montis Pelion, 5.09.1896, P. Sintenis 1277 (BRNM 8365/36, BRNM 8554/36). 
Note. Freyn (1897: 790) regards Hieracium sermonikense as a hybrid between $H$. bracteolatum Smith and $H$. racemosum Waldst. \& Kit. In my opinion, the characteristic serration of leaves indicates rather a hybrid between $H$. bracteolatum and $H$. crinitum Smith.

\section{Hieracium subvillosum var. transiens Freyn}

Fig. 12

in Velenovský, Fl. Bulg.: 345. 1891 - TyPe LOCALity: 'Inter Juniperus regionis alpinae m. Petrohan-Balkan in societate sequentis (Vs. Vel.)' - LeCtotype (designated here): Petrov Han in der Stara Planina. In der Bruckenthalia und Juniperus Formation auf den höchsten Bergketten, Aug 1887, Vandas \& Velenovský (BRNM 8586/36).

Note. According to Zahn (1923: 1038), Hieracium subvillosum var. transiens Freyn is conspecific with $H$. erythrocarpum subsp. leptobrachion (Neič. \& Zahn) Zahn. Surprisingly, however, in the same work Zahn determined a specimen with admixture of simple hairs in the capitula indumentum as $H$. erythrocarpum subsp. leptobrachion fo. transiens (Freyn) Zahn.

\section{Hieracium velenovskyi Freyn}

Fig. 13

in Velenovský, Fl. Bulg.: 346. 1891 - TyPe LOCALity: 'In herbidis alpinis formationis juniperinae in $\mathrm{m}$. Vitoša (Vel), m. Petrohan-Balkan (Vs. Vel), m. Rilo frequens (Vel)' - Lестотуре (designated here): Bulgaria. Na Vitoši, 08.1885 Velenovský (BRNM 8603/36) - SYNTYPES: Stara Planina, Petrov Han. Sehr hoch, auf grasigen Waldplätzen in der Höhe der Juniperus Formation, Jul-Aug 1887 Velenovský (BRNM 8605/36); Bulgarien Petrov Han in der Stara Planina. In der Bruckenthalia $\times$ Juniperus Formation auf der höchsten Bergkette mit H. tridentatum Fr. var., Jul-Aug 1887, Velenovský (BRNM 8666/36).
Note. This is a morphologically outstanding endemic of the flora of Bulgaria which grows to this day at all localities given in the protologue. The biggest population of Hieracium velenovskyi, numbering a few thousand plants, is in the area of Mt. Aleko in the Vitoša Mts. In 1999, together with Dr. Vladimir Vladimirov, Sofia, we found a new locality of $H$. velenovskyi on the Mt. Botev massif in the Sredna Stara Planina Mts.

\section{Hieracium vulgatum var. fastigiatum Freyn}

Fig. 14

in Velenovský, Fl. Bulg.: 344. 1891 - H. erythrocarpum subsp. acrocymum Zahn in Engler, Das Pflanzenreich IV.280: 1040. 1922 - TYPE LOCALITY: '[Bulgaria] Inter Mughos ad jugum Kobylno branište m. Rilo (Vel)' - Lестотуре (designated here): Flora Bulgarica. Inter Pinus mughus [illegible] Kobylno Branište in m. Rilo. Aug 1889, J. Velenovský (BRNM 8588/36).

ACKNOwLEDGEMENTS. I am grateful to Dr. Karel Sutorý (Curator of BRNM) for the loan of herbarium material and to the anonymous reviewer for helpful remarks on the manuscript.

\section{REFERENCES}

FreYN J. 1876. Ueber einige Pflanzen, insbesondere der österr.ungar. Flora. Oesterr. Bot. Z. 26(1): 368-372.

Freyn J. 1891. Hieracium. In: J. VelenovsKÝ (ed.), Flora Bulgarica. Descriptio et enumeratio systematica plantarum vascularium in Principatu Bulgariae sponte nascentium, pp. 336-354. Fr. Řivnáč, Pragae.

FrEYN J. 1895. Ueber neue und bemerkenswerthe orientalische Pflanzenarten. Bull. Herb. Boissier 3: 497-511 \& 643-671.

FrEYN J. 1897. Ueber neue und bemerkenswerthe orientalische Pflanzenarten. Bull. Herb. Boissier 5: 781-803.

Szeląg Z. 2012. Typification of the Hieracium (Asteraceae) names described by J. Freyn from Turkey. Polish Bot. J. 57: $347-370$. 


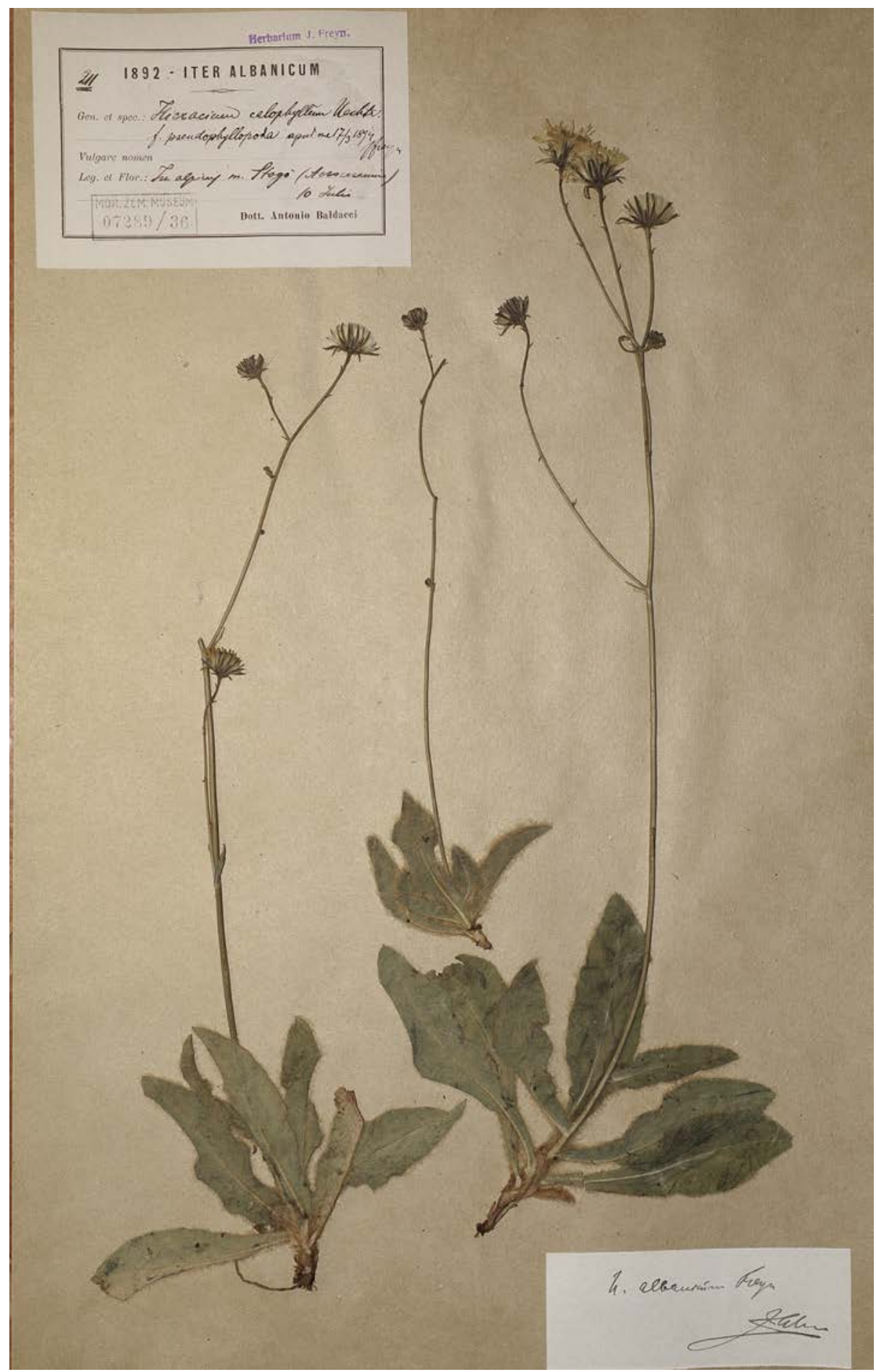

Fig. 1. Lectotype of Hieracium albanicum Freyn (BRNM 7289/36). 


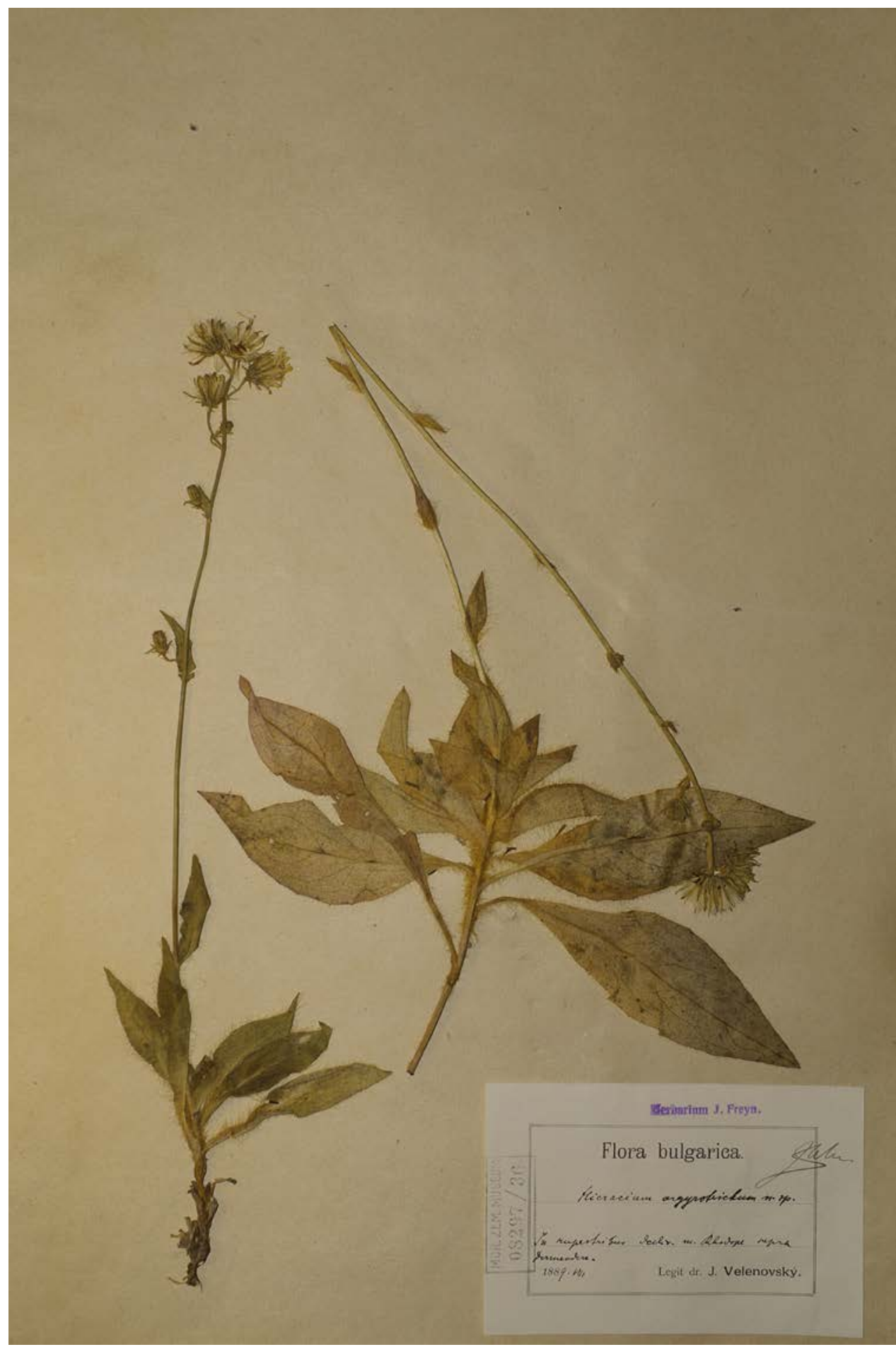

Fig. 2. Lectotype of Hieracium argyrotrichum Freyn (BRNM 8297/36). 


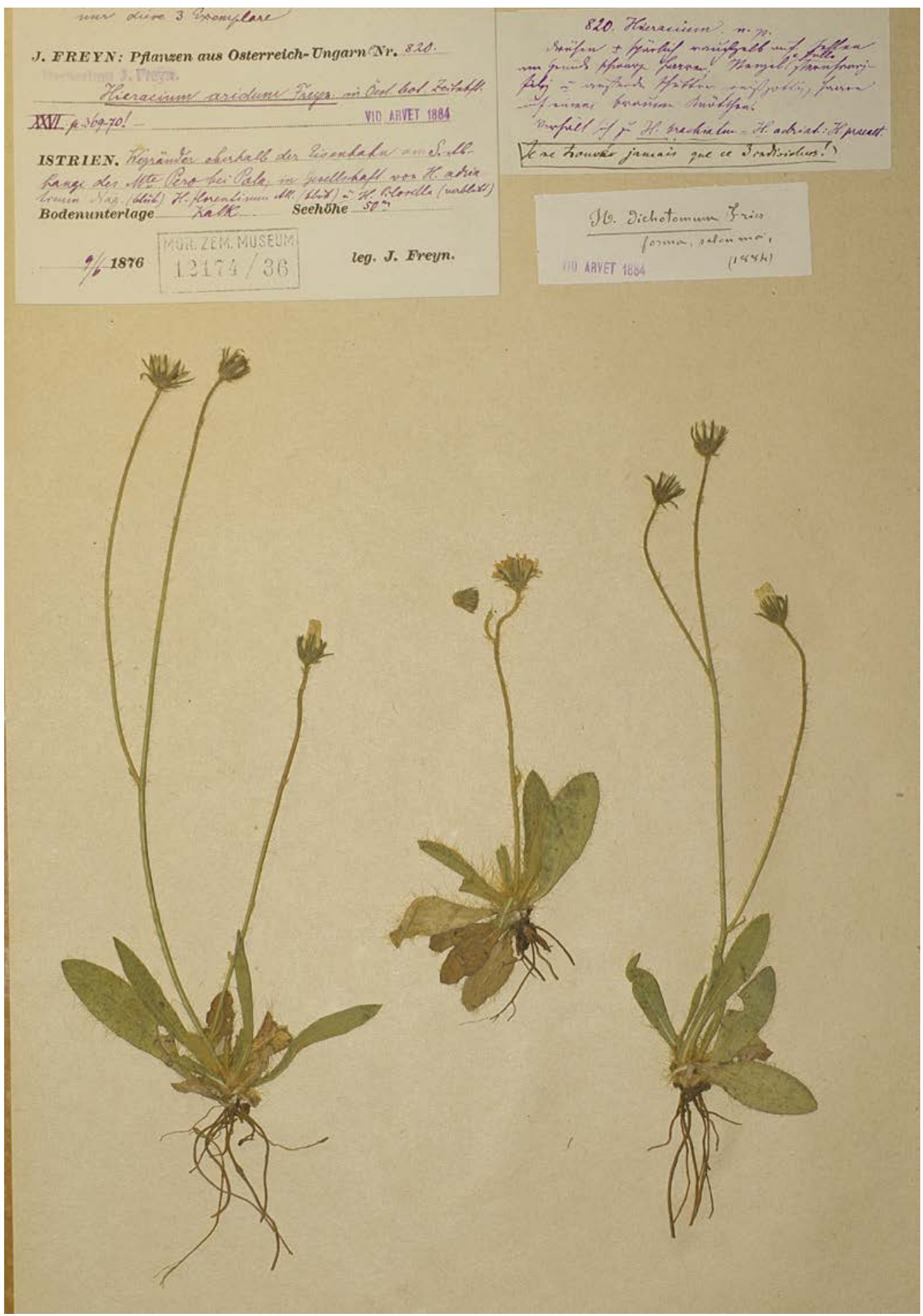

Fig. 3. Holotype of Hieracium aridum Freyn (BRNM 12174/36). 


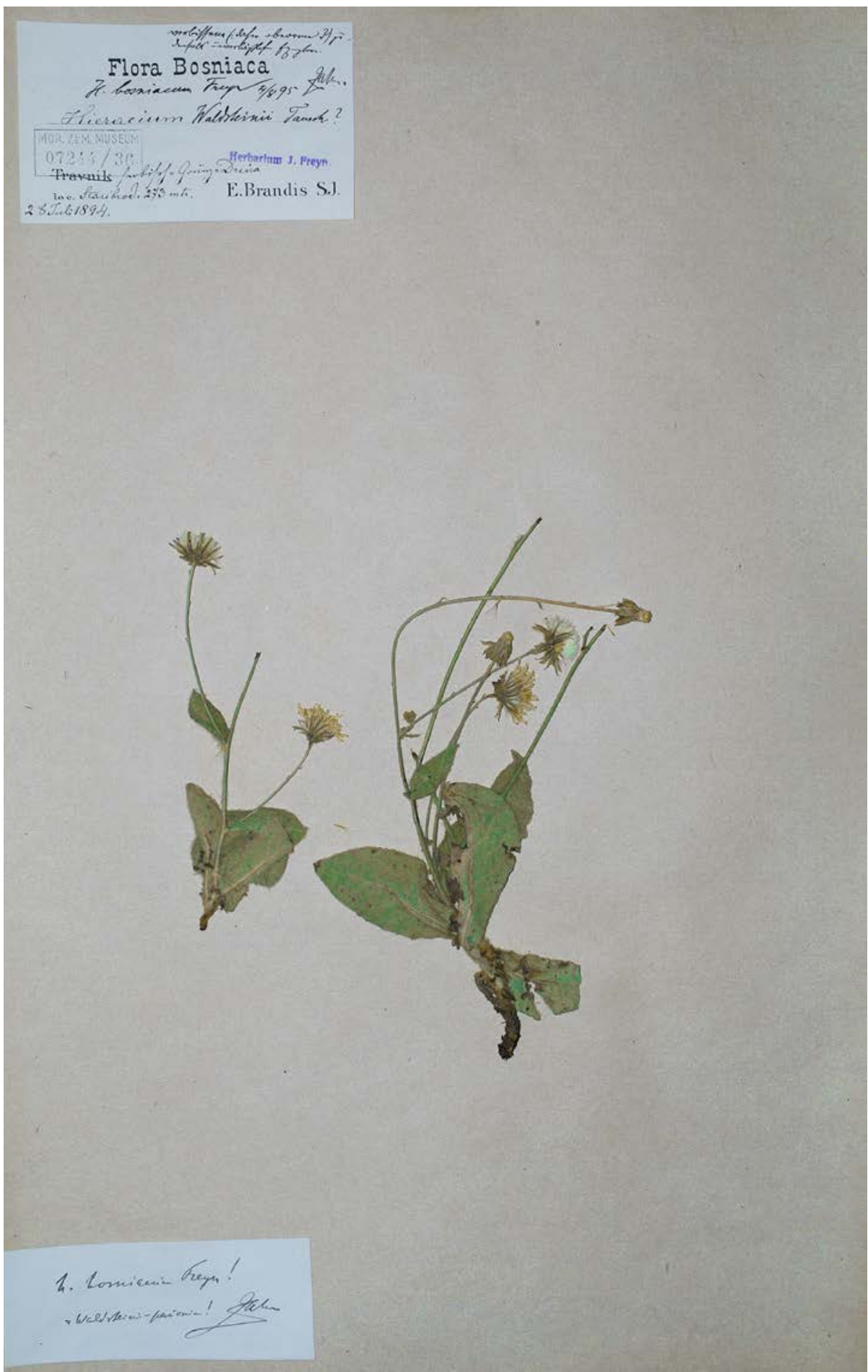

Fig. 4. Lectotype of Hieracium bosniacum Freyn (BRNM 7244/36). 


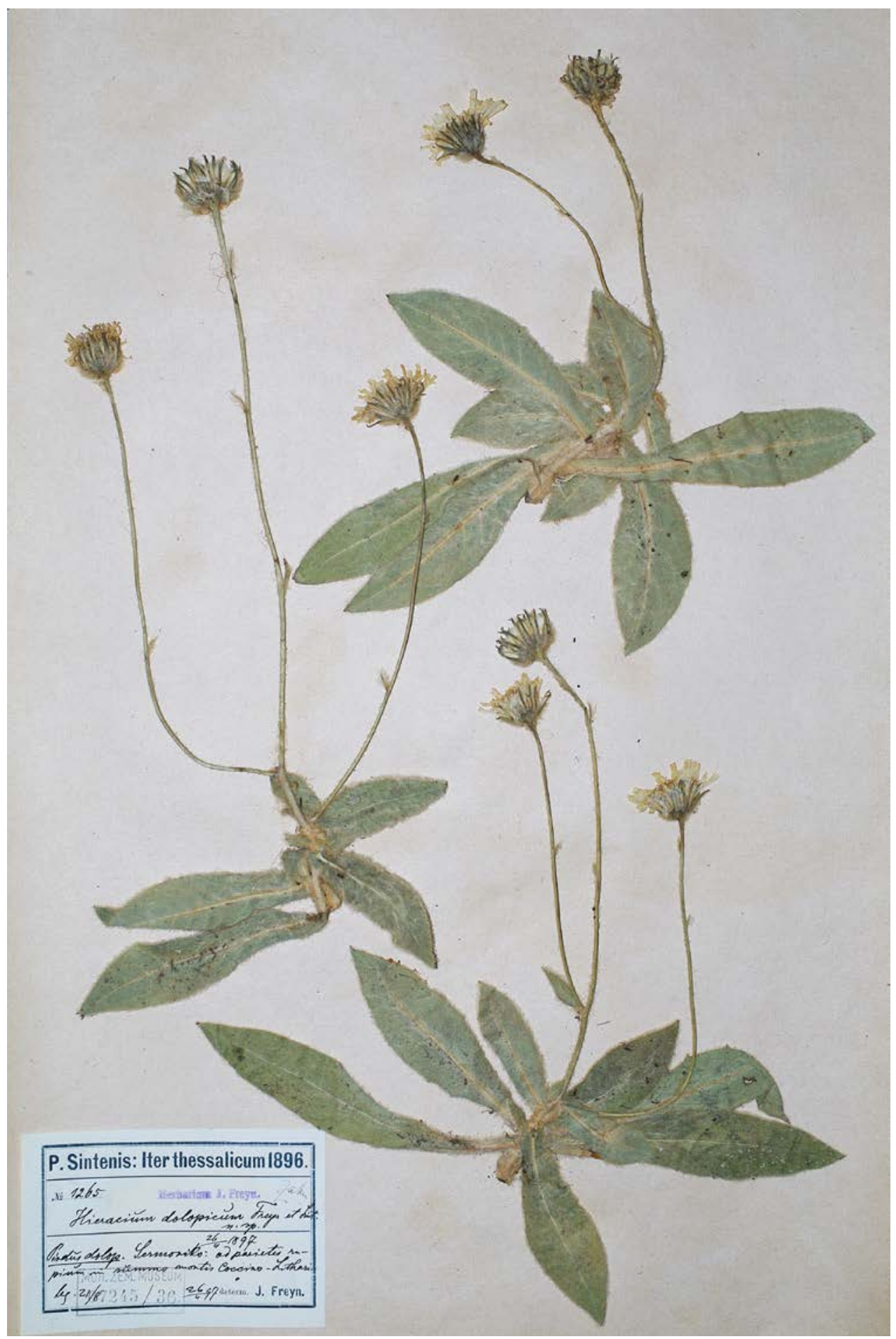

Fig. 5. Lectotype of Hieracium dolopicum Freyn \& Sint. (BRNM 7245/36). 


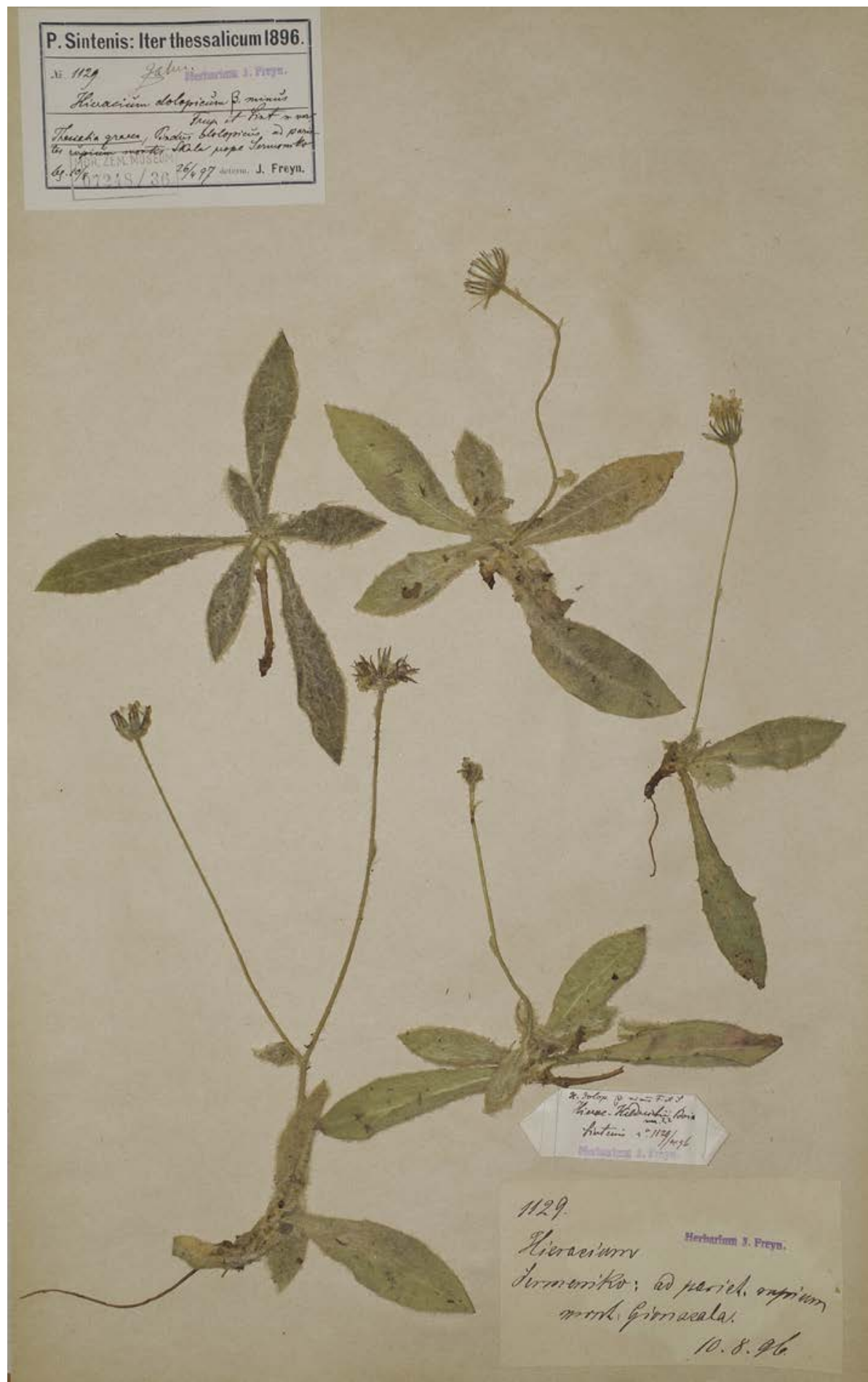

Fig. 6. Lectotype of Hieracium dolopicum var. minus Freyn \& Sint. (BRNM 7248/36). 


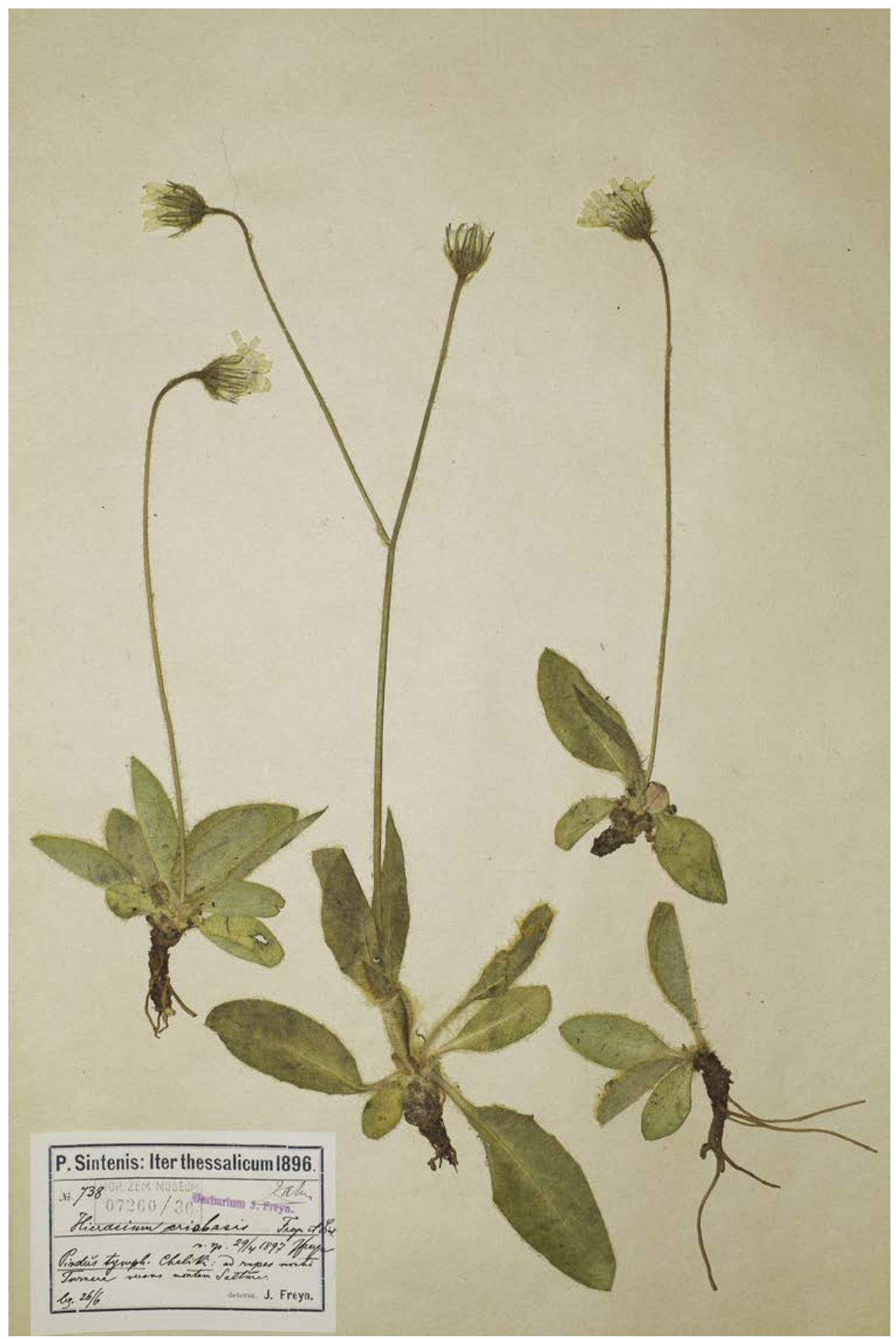

Fig. 7. Lectotype of Hieracium eriobasis Freyn \& Sint. (BRNM 7260/36). 


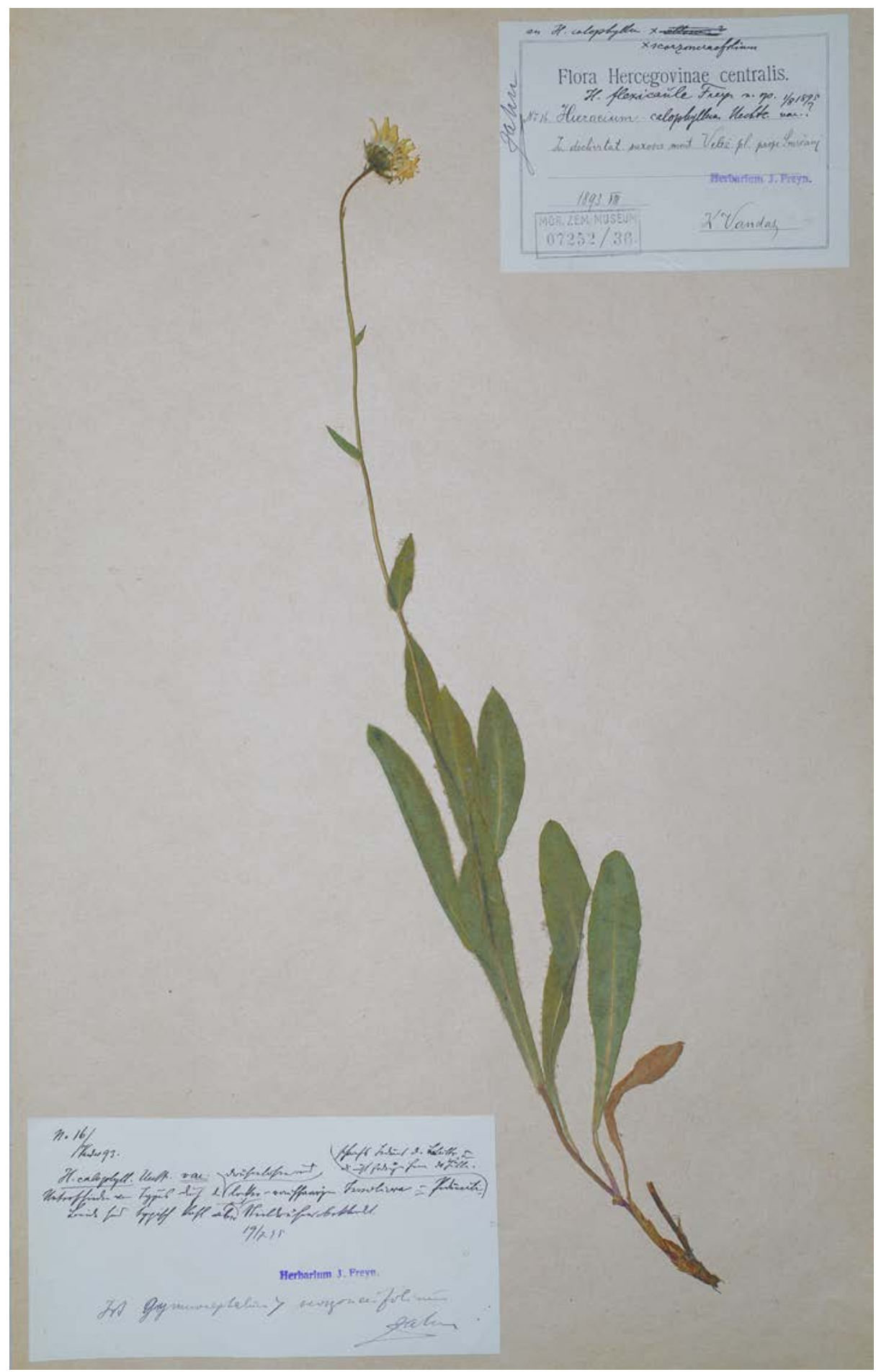

Fig. 8. Lectotype of Hieracium flexicaule Freyn \& Vandas (BRNM 7252/36). 


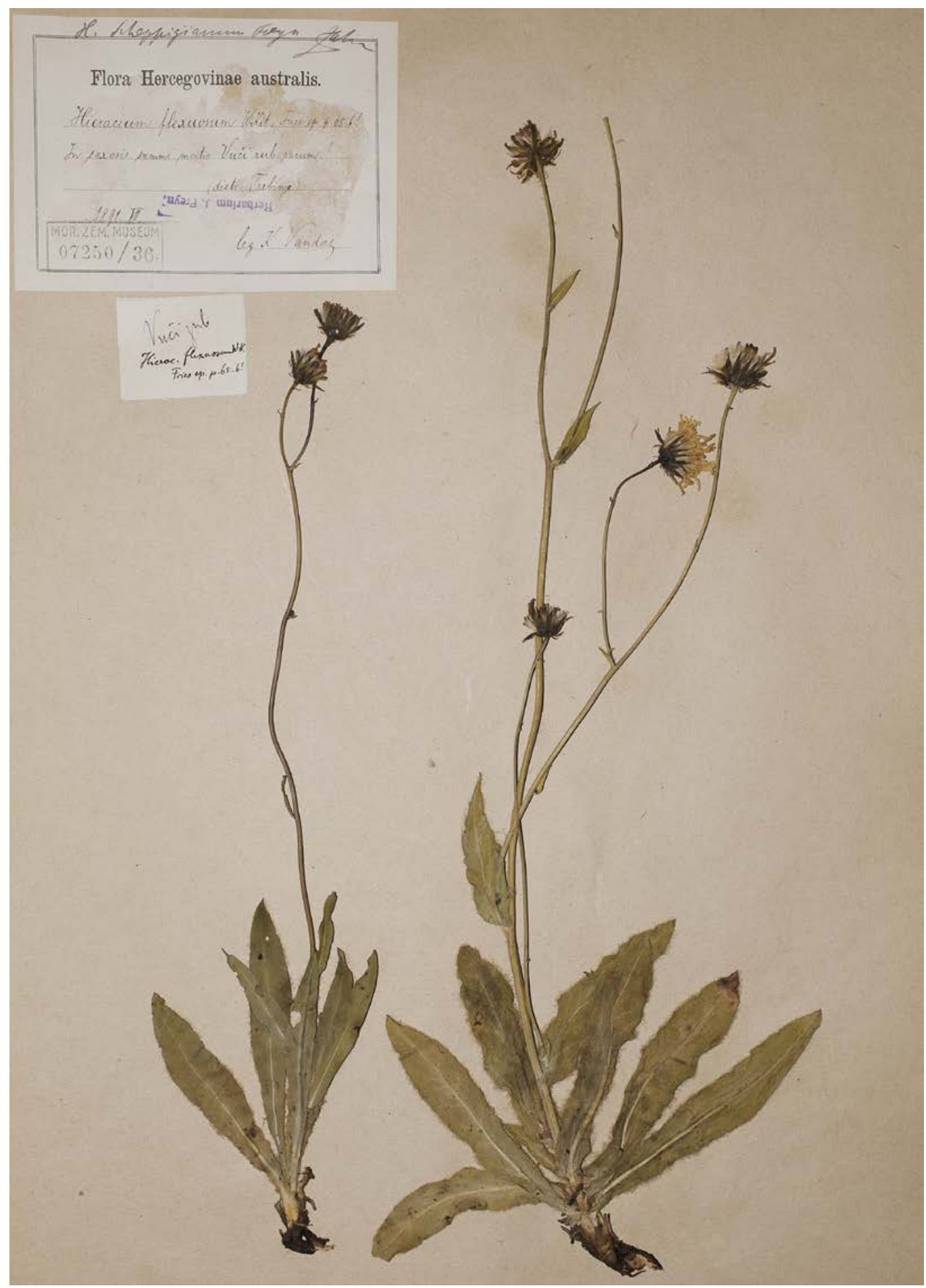

Fig. 9. Lectotype of Hieracium scheppigianum Freyn (BRNM 7250/36). 


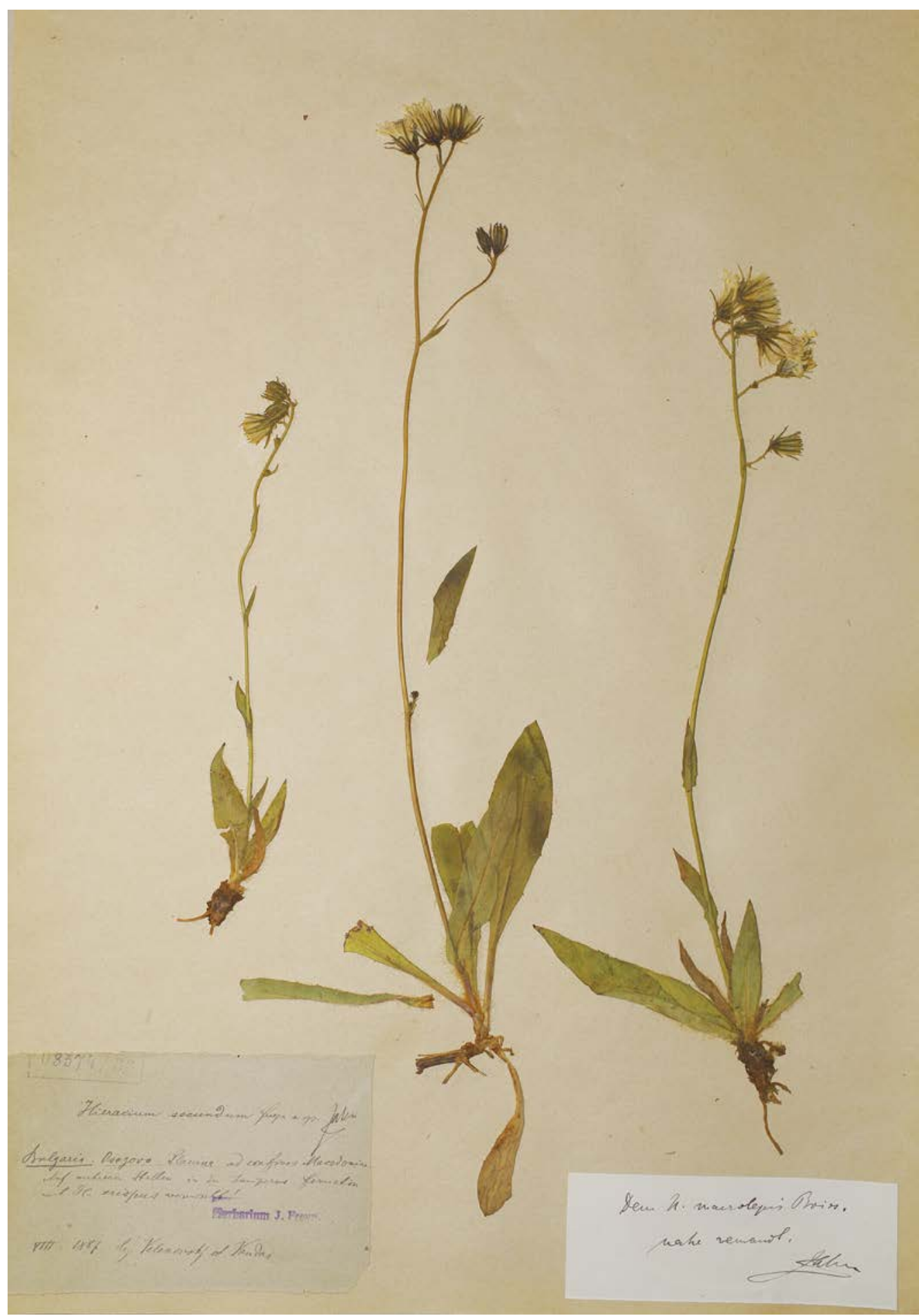

Fig. 10. Lectotype of Hieracium secundum Freyn (BRNM 8574/36). 


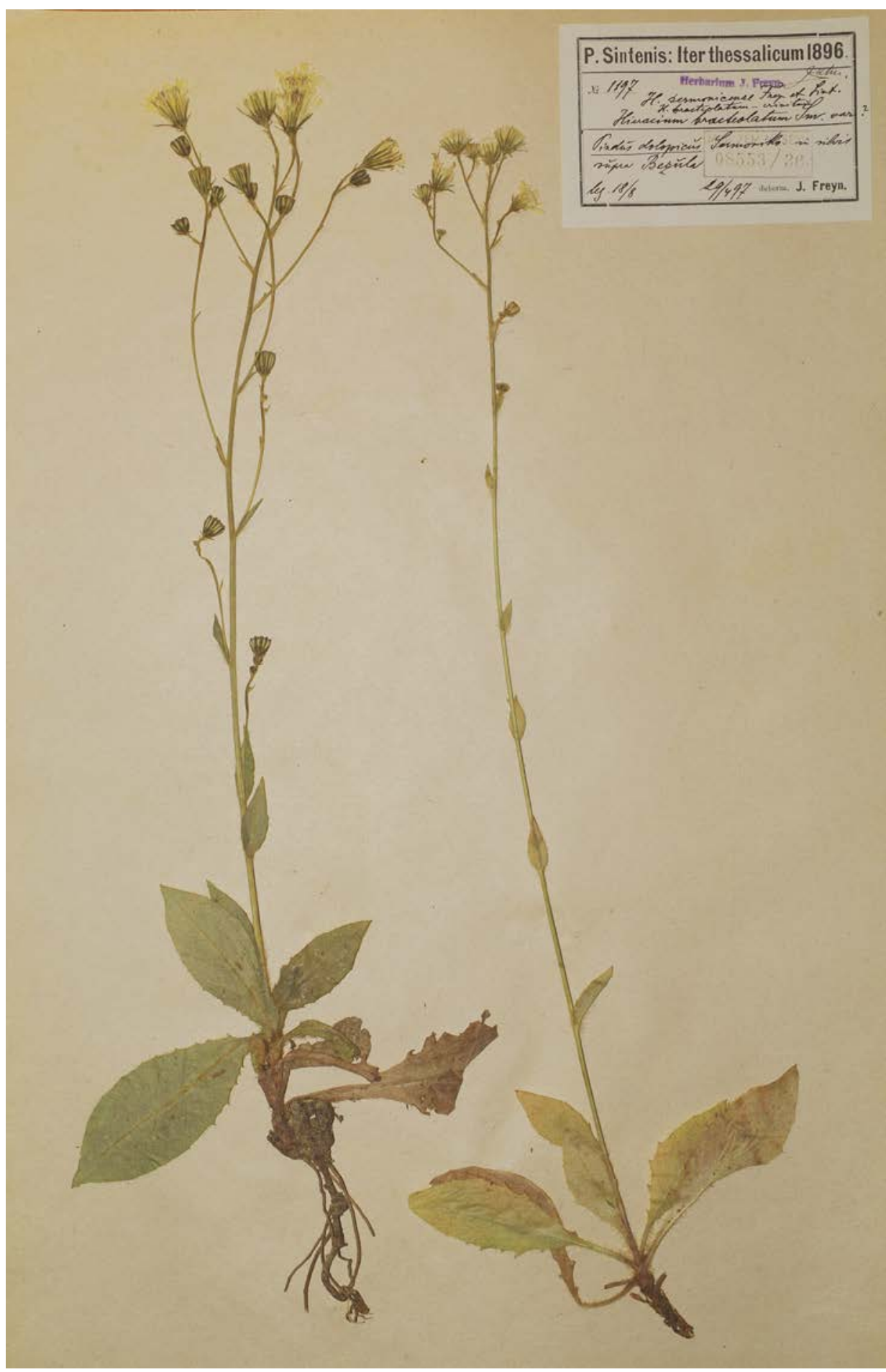

Fig. 11. Lectotype of Hieracium sermonikense Freyn \& Sint. (BRNM 8553/36). 


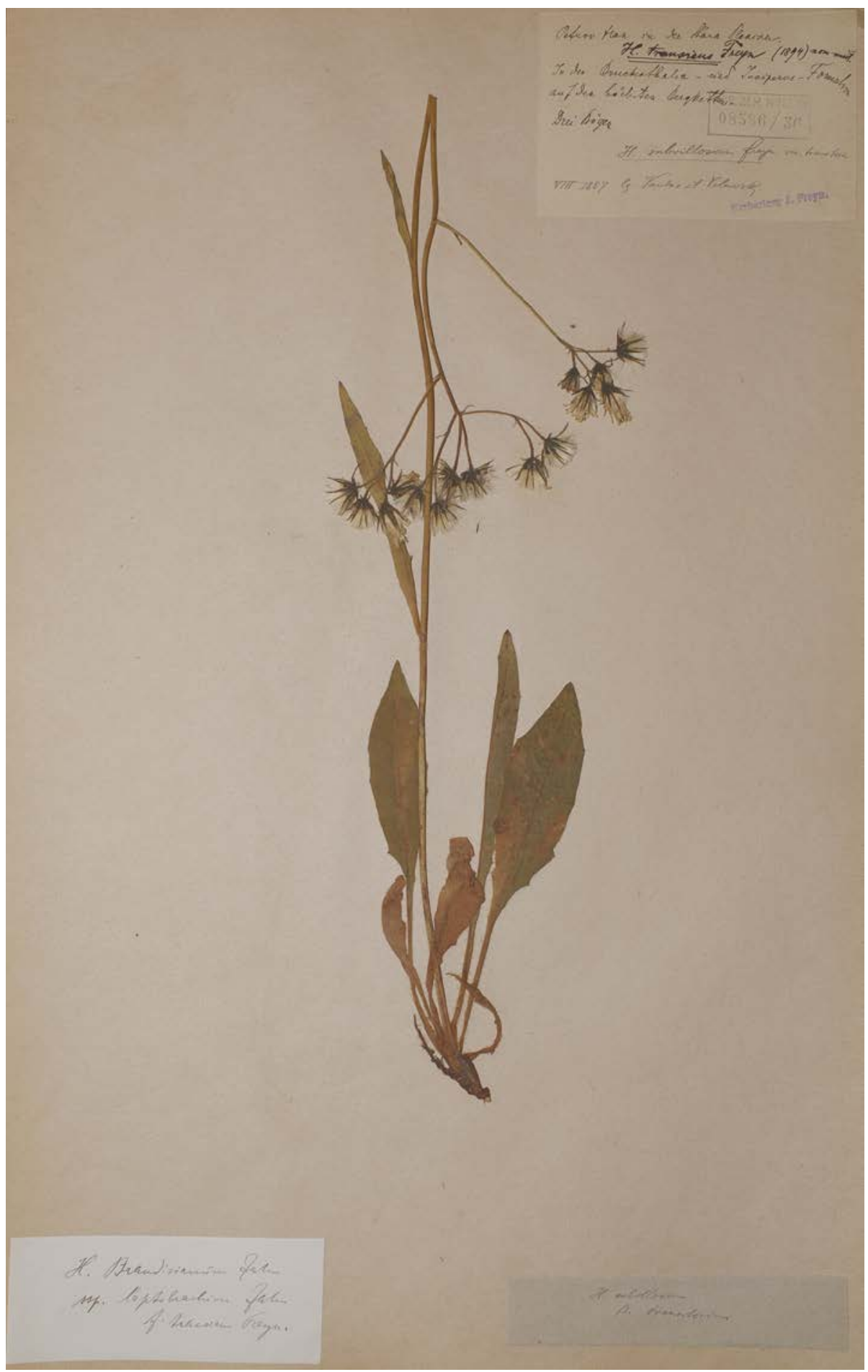

Fig. 12. Lectotype of Hieracium subvillosum var. transiens Freyn (BRNM 8586/36). 


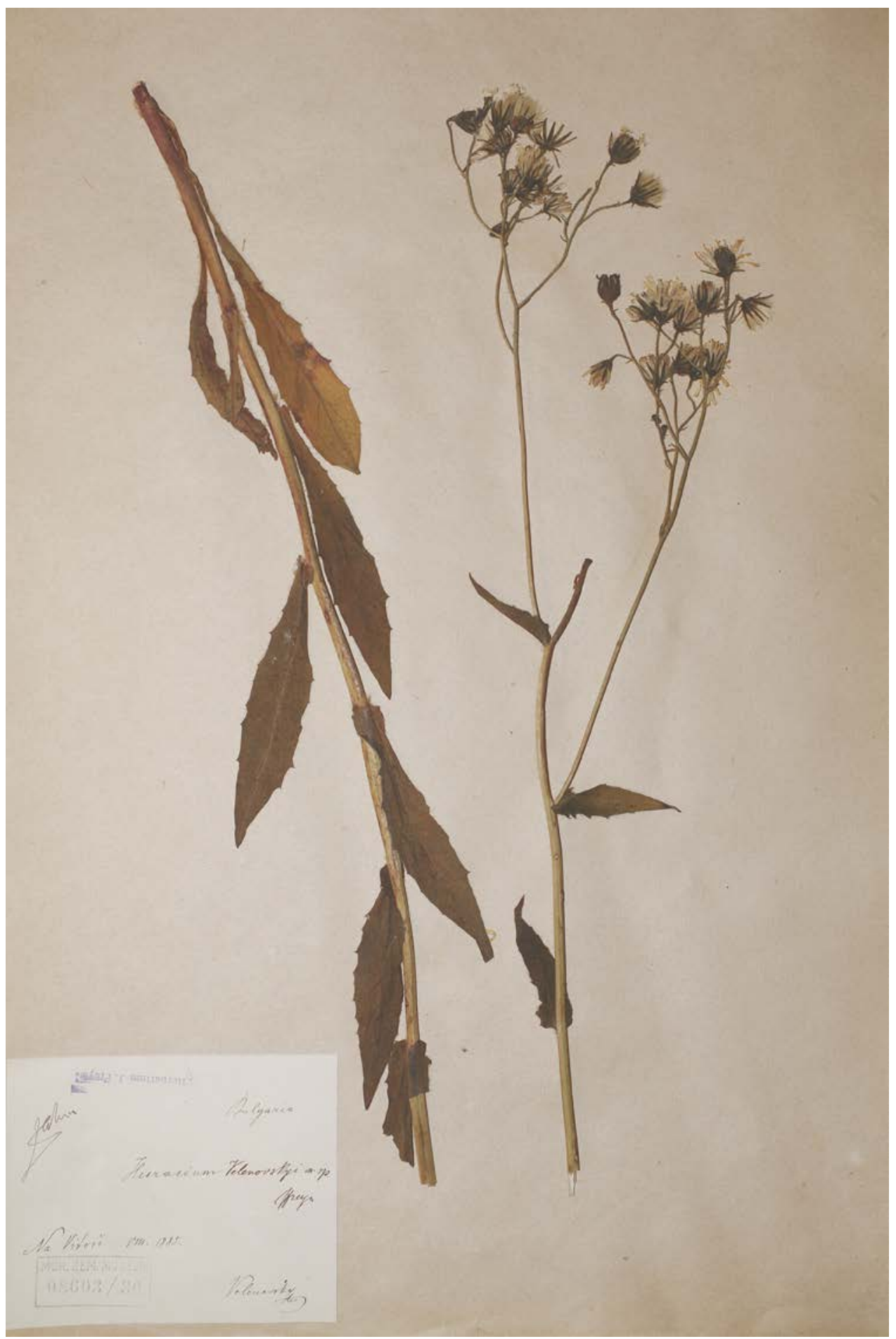

Fig. 13. Lectotype of Hieracium velenovskyi Freyn (BRNM 8603/36). 


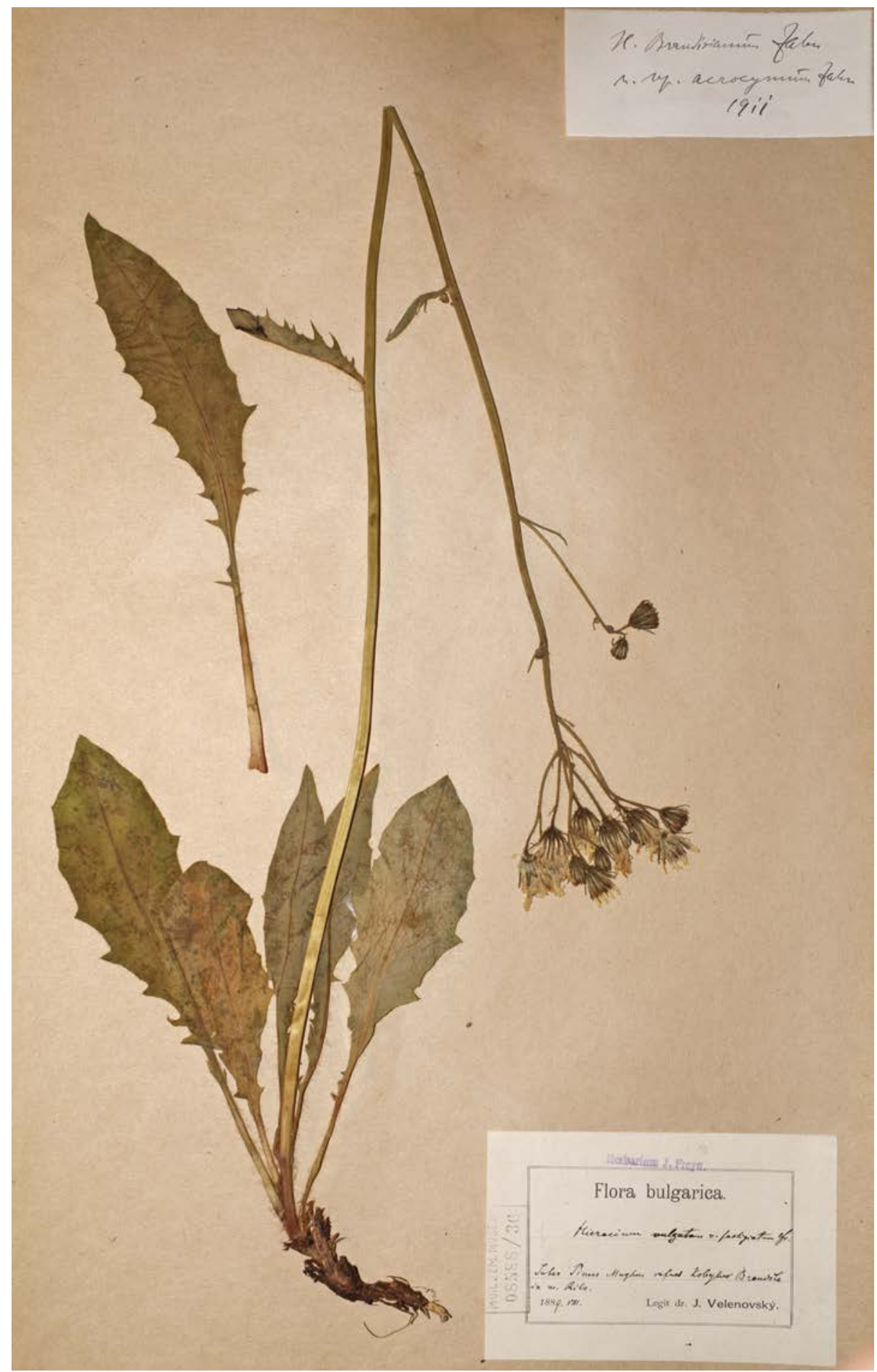

Fig. 14. Lectotype of Hieracium vulgatum var. fastigiatum Freyn (BRNM 8588/36). 